\title{
PENGARUH PENYULUHAN KESEHATAN \\ TERHADAP SIKAP REMAJA DALAM MERAWAT ORGAN REPRODUKSI
}

\author{
Sholaikhah Sulistyoningtyas, Didik Tamtomo, dan Nunuk Suryani \\ Universitas Aisyiyah Yogyakarta \\ email: tyaslauzah11@gmail.com
}

\begin{abstract}
Abstrak: Penyuluhan Kesehatan Pengaruhnyaterhadap Sikap Remaja dalam Merawat Organ Reproduksi. Penelitian ini bertujuan untuk mengetahui pengaruh penyuluhan kesehatan terhadap sikap merawat organ reproduksi ditinjau dari akses media social pada remaja putri. Penelitian menggunakan metode eksperimen semu (Quasi Eksperimen) dengan rancangan post test control group design. Populasi dalam penelitian adalah remaja putri kelas X SMAN Kerjo Karangnyar sejumlah 60 remaja putri. Kelompok perlakuan 30 remaja putri dan kelompok kontrol 30 diambil dengan teknik purposive sampling. Pengumpulan data menggunakan kuesioner dan analisis menggunakan uji beda $t$-test. Hasil penelitian menunjukkan nilai $p=0,000,0,05$. Artinya, terdapat perbedaan antara kelompok perlakuan dan kelompok control yang akses media keduanya tinggi maupun rendah. Ada pengaruh penyuluhan tentang kesehatan terhadap sikap merawat organ reproduksi ditinjau dari akses media sosial.
\end{abstract}

Kata kunci: penyuluhan, sikap,perawatan organ reproduksi, akses media sosial

Abstract:The Effect of Health Awareness on Adolescent Attitude in Treating Reproductive Organs. This study was aimed at determining the effect of health education on reproductive organs caring attitude in adolescent girls viewed from the social media. The medtod used in this study was a quasi-experimental using post test control group design. The population in the study were 60 girl students from SMAN X Kerjo Karangnyar, in which 30 girls in treatment group and the others 30 girls were in control group. The sampling were taken with purposive sampling technique. The data were collected using questionnaires and analyzed using t-test. The results show the value of $p=0.000,0.05$. It indicates that there is a difference between the treatment group and the control group media access both high and low. The conclusion is there is the influence of education on the attitudes of health care for the reproductive organs in terms of social media access.

Keywords: education, attitude, treatment of reproductive organs, social media access

\section{PENDAHULUAN}

Masa remaja (usia 11-20 tahun) adalah masa yang khusus dan penting, karena merupakan periode pematangan organ reproduksi manusia. Masa remaja disebut juga masa pubertas. Kesehatan masa remaja adalah definisi kesehatan reproduksi yaitu suatu keadaan sejahtera fisik, mental, dan sosial secara utuh, tidak semata-mata bebas dari penyakit atau kecacatan dalam semua hal yang berkaitan dengan sistem reproduksi, serta fungsi dan prosesnya.

Definisi ini sejalan dengan yang ada di Undang-Undang Nomor 36/2009 tentang Kesehatan yang menyatakan bahwa 
kesehatan reproduksi adalah keadaan sehat secara fisik mental dan sosial secara utuh tidak semata-mata bebas dari penyakit dan kecacatan yang berkaitan dengan sistem reproduksi pada laki-laki dan perempuan. Kesehatan reproduksi adalah sehat saat hamil, melahirkan dan setelah melahirkan, pengaturan kehamilan, alat kontrasepsi dan kesehatan seksual serta sistem reproduksi. Masa transisi yang unik ditandai dengan berbagai perubahan fisik, emosi, dan psikis. Remaja berada dalam situasi yang sangat peka terhadap pengaruh nilai baru, terutama bagi mereka yang tidak mempunyai daya tangkal. Mereka cenderung lebih mudah melakukan penyesuaian dengan arus globalisasi dan arus informasi yang bebas yang dapat menyebabkan terjadinya perubahan perilaku menyimpang karena adaptasi terhadap nilai nilai yang datang dari luar (Uripni, Sujianto, \& Indrawati, 2003). Arus informasi bisa berasal dari orang tua, penyuluhan media massa dan sosial.

Septalia (2010) menyatakan bahwa penyuluhan kesehatan adalah kegiatan pendidikan yang dilakukan dengan cara menyebarkan pesan atau menanamkan kenyakinan sehingga masyarakat tidak saja sadar, tahu, dan mengerti, tetapi juga mau dan bisa melakukan suatu anjuran yang ada hubungannya dengan kesehatan. Penyuluhan dalam bidang kesehatan biasanya dilakukan dengan cara promosi atau pendidikan kesehatan.

Kurnia (2005) dalam bukunya Jurnalisme Kontemporer, menyatakan bahwa internet merupakan sebuah medium terbaru yang mengkonvergensikan seluruh karakteristik media dari bentuk-bentuk yang terdahulu. Yang membuat bentukbentuk komunikasi berbeda satu sama lain bukanlah penerapaan aktual, namun perubahan dalam proses komunikasi dan perolehan informasi seperti kecakapan komunikasi, harga komunikasi, persepsi pihak-pihak yang berkomunikasidan fasilitas tempat mengakses informasi (Kurnia, 2005). Komunikasi bermedia internet merupakan konsep dan area studi yang relatif masih update. Komunikasi bermedia internet adalah penggunaan komputer berserta fasilitas dan kemampuan untuk didayagunakan sebagai penyampai pesan baik bersifat massa ataupun pribadi (Effendi, 2010). Pada dasarnya, media sosial merupakan perkembangan mutakhir dari teknologiteknologi web baru berbasis internet, yang memudahkan semua orang untuk dapat berkomunikasi, berpartisipasi, saling berbagi, dan membentuk sebuah jaringan secara online sehingga dapat menyebarluaskan berbagai konten mereka sendiri. Post di blog, tweeet, atau video youtube dapat diproduksi dan dapat dilihat secara langsung oleh jutaan orang secara gratis (Zarella, 2010).

Organ reproduksi merupakan daerah tertutup dan berlipat sehingga lebih mudah untuk berkeringat, lembab, dan kotor. Sikap dan perilaku yang buruk dalam menjaga kebersihan genitalia, seperti mencucinya dengan air kotor, memakai pembilas secara berlebihan, menggunakan celana yang tidak menyerap keringat, jarang mengganti celana dalam, dan tak sering mengganti pembalut dapat menjadi pencetus timbul infeksi. Jadi, pengetahuan dan sikap dalam menjaga kebersihan genitalia eksternal merupakan faktor penting dalam pencegahan infeksi. Berdasarkan latar belakang tersebut perlu dilakukan penelitian mengenai pengaruh penyuluhan kesehatan terhadap sikap merawat organ reproduksi ditinjau dari akses media sosial pada remaja putri di SMAN Kerjo. 


\section{METODE}

Rancangan penelitian ini adalah pre experimental design (rancangan penelitian pra eksperimen). Penelitian dilakukan di SMAN Kerjo Karanganyar. Populasi yang diteliti adalah semua remaja putri di SMAN Kerjo sebanyak 146. Sampel dipilih dengan teknik purposive sampling sebanyak 60 siswa. Eksperimen dilakukan dalam bentuk quasy experimental dengan rancangan post test control group design. Sampel dibagi ke dalam dua kelompok yaitu kelompok eksperimen dan kelompok kontrol. Masing-masing kelompok terdiri atas 30 siswa. Kelompok eksperimen diberi penyuluhan kelompok kontrol tidak diberi perlakuan.

Berdasarkan desain eksperimen yang telah ditentukan, berarti variabel independen adalah sikap perawatan organ reproduksi remaja putri. Variabel dependen adalah penyuluhan tentang kesehatan. Sikap remaja diukur dengan menggunakan instrumen berupa kuesioner. Variabel sikap dinyatakan secara numerik.
Pengujian normalitas dengan teknik kolmogorov-smirnov dilakukan sebagai prasyarat analisis. Analisis skor sikap independent $t$-test apabila data memenuhi asumsi normalitas. Mann-whitney test dilakukan apabila diketahui data tidak normal.

\section{HASIL DAN PEMBAHASAN Hasil}

Hasil penelitian pengaruh penyuluhan tentang kesehatan terhadap sikap merawat organ reproduksi ditinjau dari akses media sosial pada remaja putri di SMAN Kerjo, Karanganyar adalah sebagai berikut.

\section{Hasil dari Akses Media Sosial}

Berdasarkan hasil analisis data mengenai akses pemanfaatan media sosial pada siswa Putri SMAN Kerjo Karanganyar diperoleh data yang disajikan pada Gambar 1.

Gambar 1 menunjukkan bahwa remaja putri kelompok penyuluhan yang mempunyai akses media sosial yang tinggi

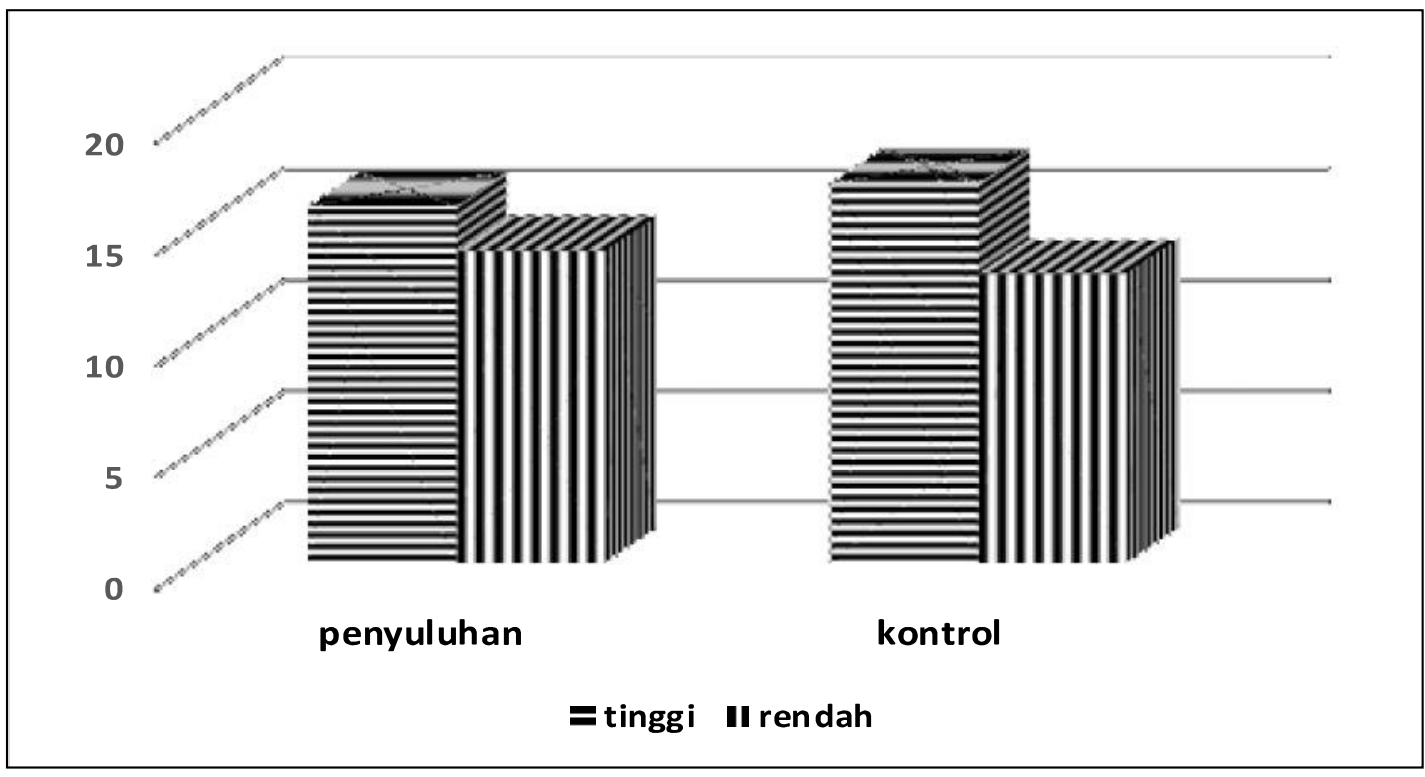

Gambar 1. Rekapitulasi Hasil Akses Media Sosial Kelompok Penyuluhan dan Kelompok Kontrol 
sebanyak 16 orang dan yang mempunyai akses media yang rendah sebanyak 14 orang. Remaja putri kelompok kontrol yang mempunyai akses media yang tinggi sebanyak 17 orang dan yang mempunyai akses media yang rendah sebanyak 13 orang.

Hasil dari Rekapitulasi Data Sikap Kelompok Penyuluhan dan Kontrol Ditinjau dari Akses Media Sosial

Berdasarkan hasil analisis data mengenai sikap kelompok penyuluhan dan kontrol ditinjau dari akses media sosial pada siswa Putri SMAN Kerjo Karanganyar diperoleh data yang disajikan melalui Gambar 2.

Gambar 2 menampilkan perbedaan sikap pada kelompok penyuluhan dan kontrol ditinjau dari akses media sosial pada remaja putri di SMA N Kerjo. Grafik tersebut menunjukkan adanya perbedaan antara penyuluhan dan kontrol ditinjau dari akses media sosial.

\section{Hasil T-test}

Uji t-test digunakan untuk mengetahui perbedaan nilai rata-rata antara kelompok perlakuan dan kelompok kontrol. Sebelum dilakukan uji $t$-test dari seluruh data di uji normalitasnya dengan uji kolmogorovsmirnov. Adapun hasil uji kolmogorovsmirnov dapat dilihat pada Tabel 1.

Tabel 1. One-Sample Kolmogorov-Smirnov Test

\begin{tabular}{llr}
\hline & & Sikap \\
\hline$N$ & & 30 \\
Normal Parameters $^{a, b}$ & Mean & 71.40 \\
& Std. & 5.544 \\
& Deviation & \\
Most Extreme & Absolute & .214 \\
Differences & Positive & .117 \\
& Negative & -.214 \\
Kolmogorov-Smirnov Z & & 1.171 \\
Asymp. Sig. (2-tailed) & & .129 \\
\hline Keterangan:
\end{tabular}

Keterangan:

a. Test distribution is normal

b. Calculated from data

Tabel 1 menunjukkan bahwa data berdistribusi normal dengan nilai asymp. sign (2-tailed lebih besar dari 0,05). Hasil uji kolmogorov-smirnov menunjukkan data berdistribusi normal. Uji t-test dilakukan dengan hasil yang disajikan pada Tabel 2 sampai dengan Tabel 7.

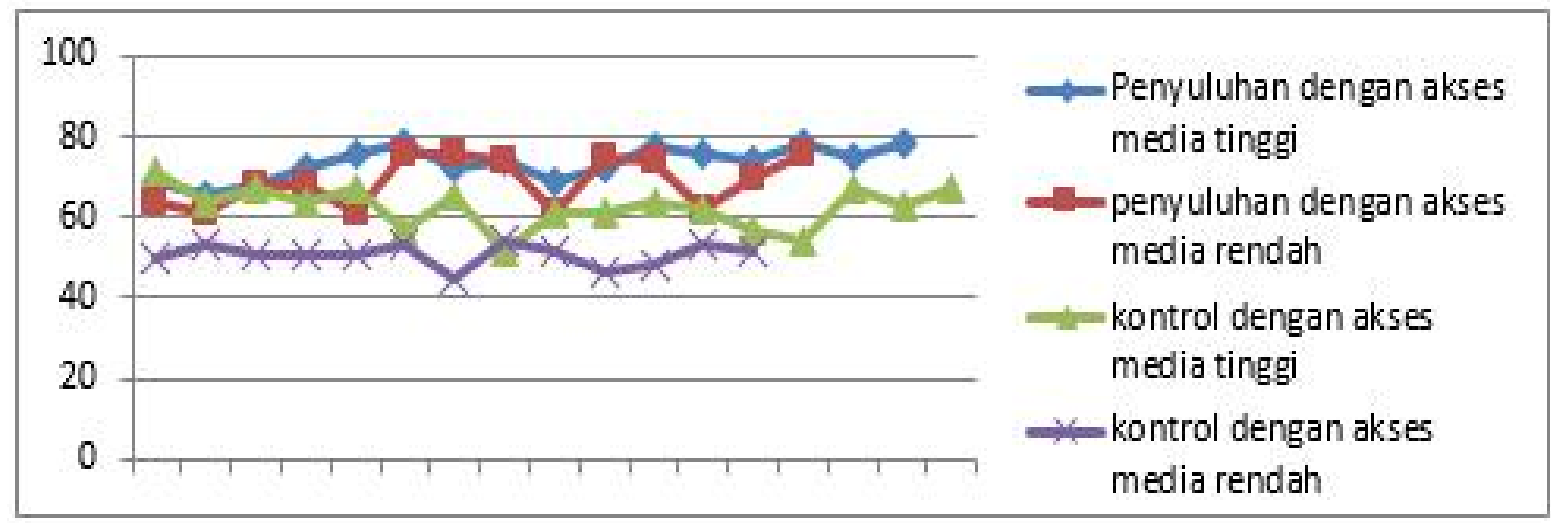

Gambar 2. Rekapitulasi Sikap Kelompok Penyuluhan dan Kontrol Ditinjau dari Akses Media Sosial 
Tabel 2. Hasil Uji Paired T-Test Kelompok Penyuluhan

\begin{tabular}{lrrrrr}
\hline & \multicolumn{2}{c}{ Paired T-test } & & \multicolumn{2}{c}{ Sig } \\
\cline { 2 - 3 } & Mean & $\begin{array}{c}\text { Std. } \\
\text { Deviasi }\end{array}$ & $T$ & Df & $\begin{array}{c}\text { Sigiled }) \\
\text { (2-taile }\end{array}$ \\
\hline $\begin{array}{l}\text { Pair tinggi } \\
\text { rendah }\end{array}$ & 3,857 & 5,489 & 2,629 & 13 &, 021 \\
\hline
\end{tabular}

Tabel 3. Hasil Uji Paired T-Test Kelompok Kontrol

\begin{tabular}{lrrrrr}
\hline & \multicolumn{2}{c}{ Paired T-test } & & \multicolumn{2}{c}{ Sig } \\
\cline { 2 - 3 } & Mean & $\begin{array}{c}\text { Std. } \\
\text { Deviasi }\end{array}$ & $T$ & Df & $\begin{array}{c}\text { Sigiled) } \\
\text { (2-tailed }\end{array}$ \\
\hline $\begin{array}{l}\text { Pair tinggi } \\
\text { 1 rendah }\end{array}$ & 12,538 & 5,379 & 8,404 & 12 &, 000 \\
\hline
\end{tabular}

Tabel 4. Hasil Uji Independent T-Test Kelompok dan Kelompok Kontrol yang Mempunyai Akses Media Tinggi

\begin{tabular}{llccccc}
\hline & & \multicolumn{3}{c}{$\begin{array}{c}\text { Levene's test for } \\
\text { equality of variance }\end{array}$} & t-test for equality of means \\
\cline { 2 - 7 } & $F$ & Sig & $T$ & $D f$ & $\begin{array}{l}\text { Sig (to } \\
\text { tailed) }\end{array}$ \\
\hline \multirow{2}{*}{ Sikap } & $\begin{array}{l}\text { Equal variance assumed } \\
\text { Equal variances not assumed }\end{array}$ & .000 & 0.987 & 7.004 & 31 & .000 \\
\hline
\end{tabular}

Tabel 5. Hasil Uji Independent T-Test Kelompok Penyuluhan yang Akses Media Tinggi dengan Kelompok Kontrol Akses Media Rendah

\begin{tabular}{|c|c|c|c|c|c|c|}
\hline & & \multicolumn{2}{|c|}{$\begin{array}{l}\text { Levene's test for } \\
\text { equality of variance }\end{array}$} & \multicolumn{3}{|c|}{ t-test for equality of means } \\
\hline & & $F$ & Sig & $T$ & $D f$ & $\begin{array}{l}\text { Sig (to } \\
\text { tailed) }\end{array}$ \\
\hline \multirow[t]{2}{*}{ Sikap } & Equal variance assumed & 2.573 & 0.120 & 17,323 & 27 & .000 \\
\hline & Equal variances not assumed & & & 17.973 & 26.489 & .000 \\
\hline
\end{tabular}

Tabel 6. Hasil Uji Independent T-Test Kelompok Penyuluhan yang Akses Media Rendah dengan Kelompok Kontrol Yang Akses Media Tinggi

\begin{tabular}{ccccccc}
\hline & & \multicolumn{3}{c}{$\begin{array}{c}\text { Levene's test for } \\
\text { equality of variance }\end{array}$} & t-test for equality of means \\
\cline { 3 - 7 } & $F$ & Sig & $T$ & $D f$ & $\begin{array}{c}\text { Sig (to } \\
\text { tailed) }\end{array}$ \\
\hline \multirow{2}{*}{ Sikap } & $\begin{array}{l}\text { Equal variance assumed } \\
\text { Equal variances not assumed }\end{array}$ & 5.017 & 0.033 & 3.104 & 29 & .004 \\
\hline
\end{tabular}


Tabel 7. Hasil Uji Independent T-test Kelompok Penyuluhan dengan Kelompok Kontrol yang Akses Keduanya Rendah

\begin{tabular}{clcccccc}
\hline & & \multicolumn{3}{c}{$\begin{array}{c}\text { Levene's test for } \\
\text { equality of variance }\end{array}$} & t-test for equality of means \\
\cline { 2 - 7 } & $F$ & Sig & $T$ & $D f$ & $\begin{array}{c}\text { Sig (to } \\
\text { tailed) }\end{array}$ \\
\hline Sikap & Equal variance assumed & 14.908 & $0 . .001$ & 9.475 & 25 & .000 \\
& Equal variances not assumed & & & 9.998 & 18.289 & .000 \\
\hline
\end{tabular}

Tabel 2 menunjukkan bahwa dari hasil out put SPSS diketahui bahwa nilai kelompok penyuluhan yang akses media sosial tinggi dan akses media rendah sama-sama tinggi tidak ada perbedaan. Hal ini ditunjukkan dengan nilai $\mathrm{p}=0,021$. Nilai $p$ tersebut ( $p>0,05$ ) maka Ha ditolak dan Ho diterima. Artinya, tidak ada beda rerata antara nilai kelompok penyuluhan yang akses media tinggi dengan akses media rendah.

Tabel 3 menunjukkan bahwa dari hasil out put SPSS diketahui bahwa nilai $p$ $=0,000$ dimana nilai $\mathrm{p}$ tersebut $(\mathrm{p}<0,05)$ maka Ho ditolak. Artinya, ada beda rerata antara nilai kelompok kontrol yang akses media tinggi dengan akses media rendah.

Tabel 4 menunjukkan nilai p sebesar $, 000<0,05$ atau nilai $t_{\text {hitung }}$ sebesar 6.867 $>\mathrm{t}_{\text {tabel }}$ sebesar 1,980. Dengan demikian menunjukkan bahwa Ho ditolak dan $\mathrm{Ha}$ diterima. Artinya, ada perbedaan ratarata yang signifikan antara kelompok penyuluhan dan kelompok kontrol yang mempunyai akses media keduanya tinggi.

Tabel 5 menunjukkan nilai p sebesar $, 000<0,05$ atau nilai $t_{\text {hitung }}$ sebesar 17,323 $>t_{\text {tabel }}$ sebesar 1,980. Dengan demikian menunjukkan bahwa Ho ditolak dan $\mathrm{Ha}$ diterima. Artinya, ada perbedaan ratarata yang signifikan nilai sikap antara kelompok perlakuan yang akses media tinggi dengan kelompok kontrol yang akses media rendah.

Tabel 6 menunjukkan nilai p sebesar $, 004<0,05$ atau nilai $t_{\text {hitung }}$ sebesar 3,104 $>t_{\text {tabel }}$ sebesar 1,980. Dengan demikian menunjukkan bahwa Ho ditolak dan $\mathrm{Ha}$ diterima. Artinya, ada perbedaan ratarata yang signifikan perubahan nilai sikap antara kelompok perlakuan yang akses media rendah dengan kelompok kontrol yang akses media tinggi.

Tabel 7 menunjukkan nilai p sebesar $, 000<0,05$ atau nilai $t_{\text {hitung }}$ sebesar $9,475>$ $\mathrm{t}_{\text {tabel }}$ sebesar 1,980. Dengan demikian menunjukkan bahwa Ho ditolak dan $\mathrm{Ha}$ diterima. Artinya, ada perbedaan ratarata yang signifikan perubahan nilai sikap antara kelompok perlakuan dengan kelompok kontrol yang akses keduanya rendah.

\section{Pembahasan}

Penelitian diawali dengan membagi 2 kelompok yaitu kelompok perlakuan dan kelompok kontrol. Pada kelompok perlakuan remaja putri langsung diberikan penyuluhan tentang kesehatan reproduksi. Selanjutnya dilakukan penilaian dengan menggunakan kuesioner langsung setelah penyuluhan. Pada kelompok kontrol langsung dibagikan kuesioner dan dilakukan penilaian tanpa diberi perlakuan apapun. Berdasarkan kedua 
skor sikap merawat organ reproduksi maka dilakukan pengujian analisis data untuk mengetahui pengaruh penyuluhan tentang kesehatan terhadap sikap merawat organ reproduksi eksternal ditinjau dari akses media sosial pada remaja putri di SMAN Kerjo Karanganyar.

Hasil pengujian pada kelompok penyuluhan didapatkan hasil ada 16 remaja putri mempunyai akses media tinggi dan 14 remaja putri mempunyai akses media rendah. Pada kelompok perlakuan/ penyuluhan dari hasil analisis paired $t$-test diperoleh nilai $\mathrm{p}=0,012$ dimana nilai $\mathrm{p}$ tersebut $(p>0,05)$ maka Ha ditolak dan Ho diterima. Artinya, tidak ada beda rerata antara nilai kelompok penyuluhan yang akses media tinggi dengan akses media rendah. Hal ini terjadi karena penilaian dilakukan langsung setelah penyuluhan. Pengetahuan atau pemahaman remaja putri tentang kesehatan organ reproduksi masih teringat jelas sehingga pada kelompok remaja putri yang akses media tinggi dengan akses media rendah tidak terdapat perbedaan yang mencolok. Hal ini sesuai dengan pendapat Notoatmojo (2007) yang menyatakan metode penyuluhan individual berupa ceramah dapat digunakan untuk sasaran dengan pendidikan tinggi maupun rendah. Dalam memberikan penyuluhan, peneliti dan responden terjalin hubungan kekeluargaan sehingga responden tidak takut untuk bertanya maupun mengemukakan pendapatnya.

Selain itu juga sesuai dengan pendapat Septalia (2010) yang menyatakan penyuluhan kesehatan adalah kegiatan pendidikan yang dilakukan dengan cara menyebarkan pesan atau menanamkan kenyakinan sehingga masyarakat tidak saja sadar, tahu, dan mengerti tetapi juga mau dan bisa melakukan suatu anjuran yang ada hubungannya dengan kesehatan.
Penyuluhan dalam bidang kesehatan biasanya dilakukan dengan cara promosi atau pendidikan kesehatan.

Hasil analisis pada kelompok penyuluhan yang akses media tinggi dengan kelompok kontrol yang akses media tinggi menggunakan independent t-test diperoleh hasil signifikan yaitu nilai p sebesar $, 000<0,05$. Hal ini menunjukkan bahwa ada perbedaan rata-rata yang signifikan antara kelompok penyuluhan dan kelompok kontrol yang akses media keduanya tinggi. Hasil analisis kelompok penyuluhan dengan akses media tinggi dan kelompok kontrol dengan akses media rendah diperoleh hasil dengan nilai p sebesar $, 000<0,05$ atau nilai $t_{\text {hitung }}$ sebesar 17,452 $>t_{\text {tabel }}$ sebesar 1,980. Hal ini menunjukkan bahwa Ho ditolak dan Ha diterima. Artinya, ada perbedaan ratarata yang signifikan nilai sikap antara kelompok perlakuan yang akses media tinggi dengan kelompok kontrol yang akses media rendah.

Hasil analisis kelompok penyuluhan dengan media rendah dengan kelompok control akses media tinggi diperoleh nilai p sebesar $, 004<0,05$ atau nilai $t_{\text {hitung }}$ sebesar 3,179 $>\mathrm{t}_{\text {tabel }}$ sebesar 1,980. Hal ini menunjukkan bahwa Ho ditolak dan Ha diterima. Artinya, ada perbedaan ratarata yang signifikan perubahan nilai sikap antara kelompok perlakuan yang akses media rendah dengan kelompok kontrol yang akses media tinggi

Hasil analisis kelompok penyuluhan dan kelompok kontrol yang akses keduanya rendah diperoleh nilai p sebesar $, 000<0,05$ atau nilai $t_{\text {hitung }}$ sebesar 9,475> $\mathrm{t}_{\text {tabel }}$ sebesar 1,980. Hal ini menunjukkan bahwa Ho ditolak dan Ha diterima. Artinya, ada perbedaan rata-rata yang signifikan perubahan nilai sikap antara kelompok perlakuan dengan kelompok kontrol yang akses keduanya rendah. 
Hasil analisis di atas menunjukkan bahwa dengan penyuluhan dan akses media sosial mempengaruhi peningkatan sikap pada remaja putri menjadi lebih baik. Hal ini sesuai dengan pendapat Walgito (2003) menjelaskan beberapa faktor yang dapat mempengaruhi sikap seseorang. Salah satunya adalah pengetahuan, pengetahuan dapat diperoleh melalui penyuluhan. Dalam penelitian ini, penyuluhan kesehatan yang diberikan pada masa remaja dapat merubah sikap remaja putri dari belum paham menjadi paham. Remaja dapat mengevaluasi dengan tepat cara merawat organ reproduksi eksternal. Pengertian dari sikap adalah evaluasi umum yang dibuat manusia terhadap dirinya sendiri, orang lain, objek atau issue. Selain itu juga sikap adalah kondisi mental yang kompleks yang melibatkan keyakinan, perasaan, dan disposisi untuk bertindak secara tertentu (Wawan \& Dewi, 2011).

Adanya penyuluhan yang dilakukan pada remaja putri sikap yang awalnya bersifat negatif yaitu terdapat kecenderungan untuk menjauhi, menghindari, merawat organ reproduksi eksternal bisa berubah menjadi sikap yang bersifat positif yaitu berupa kecenderungan untuk bertindak seperti menyenangi dan merasa tenang dan nyaman sertasiap melakukan perawatan dengan tepat dengan lebih baik. Penyuluhan ini dilakukan kepada remaja putri di SMAN Kerjo Karanganyar, agar remaja putri tahu dan mengerti serta merasa nyaman dan siap melakukan perawatan dengan tepat dan benar.

Selain penyuluhan, dengan sering mengakses media sosial juga mempengaruhi sikap karena dengan mengakses media sosal juga meningkatkan pengetahuan remaja putri secara mandiri. Media sosial merupakan fasilitas atau tempat mengakses informasi (Kurnia, 2005)

Penyuluhan yang diberikan dengan metode dan media yang tepat merupakan salah satu faktor yang mempengaruhi seseorang untuk tertarik dan mau melakukan anjuran yang diberikan saat penyuluhan. Petugas kesehatan sebagai orang yang berperan dalam memberikan penyuluhan juga sangat mempengaruhi keberhasilan penyuluhan ini (Notoatmodjo, 2007).

Pengetahuan merupakan salah satu faktor yang mempengaruhi sikap dalam merawat organ reproduksi. Perubahan dalam proses komunikasi dan perolehan informasi dari akses media sosial seperti kecakapan komunikasi, harga komunikasi, persepsi pihak-pihak yang berkomunikasi dan fasilitas tempat mengakses informasi (Kurnia, 2005) mempengaruhi sikap remaja putri.

Komunikasi dengan media sosial melalui internet mempengaruhi sikap pada remaja putri dalam merawat organ reproduksi eksterna dan menambah informasi dan kemampuan serta pemahaman bagi pengguna. Ini sesuai dengan pendapat Effendi (2010) yang menyatakan komunikasi bermedia internet merupakan konsep dan area studi yang relatif masih update. Komunikasi bermedia internet adalah penggunaan komputer berserta fasilitas dan kemampuan untuk didayagunakan sebagai penyampai pesan baik bersifat massa ataupun pribadi (Effendi, 2010).

Penelitian ini juga didukung oleh penelitian-penelitian terdahulu yaitu: pertama, Julia, Yuliatun, \& Nastiti (2013) yang meneliti tentang pengaruh penyuluhan kesehatan tentang kebersihan genetalia terhadap upaya pencegahan keputihan pada remaja putri di SMPN Dau Malang. Didapatkan hasil yang signifikan 
$(\mathrm{p}=0,000)$. Dari data tersebut dapat disimpulkan bahwa terdapat pengaruh positif penyuluhan kesehatan tentang kebersihan genitalia terhadap upaya pencegahan keputihan pada remaja putri di SMPN 1 Dau Malang.

Kedua, Indrawati (2013) dengan judul Peningkatan Pengetahuan Siswi Kelas VIII SMPN 10 Surabaya tentang Kebersihan Organ Reproduksi Wanita melalui Tutor Sebaya yang Dilakukan oleh Kader. Hasil prates menunjukkan 58\% siswi mendapatkan nilai tidak baik (<56) dan 39\% dengan nilai cukup (5678) kemudian 3\% mendapat nilai baik (79-100) setelah dilakukan penyuluhan tentang kebersihan organ reproduksi melalui metode tutor sebaya yang dilakukan oleh Kader Kesehatan Remaja (KKR) maka hasil posttest tidak satupun siswi yang mendapat nilai tidak baik $(0 \%)$, siswi yang mendapatkan nilai cukup 49\%, dan $53 \%$ mendapat nilai baik. Berdasarkan penelitian ini dapat disimpulkan bahwa melalui metode tutor sebaya oleh KKR ternyata dapat meningkatkan pengetahuan tentang kebersihan organ reproduksi siswi kelas VIII SMPN 10 Surabaya.

Ketiga, Puspitaningrum, Suryoputro, \& Widagdo (2012) yang meneliti tentang faktor-faktor yang mempengaruhi praktikpraktik organ genetalia eksternal pada anak usia 10-11 tahun yang mengalami menarche dini di sekolah dasar. Metode yang digunakan dalam penelitian ini adalah kuantitatif, dengan analisis multivariat $\mathrm{OR}=1,213$. Artinya, responden yang menyatakan pernah mendapatkan informasi dari orang tua tentang cara perawatan organ genitalia eksternal mempunyai kemungkinan 1,2 kali lebih besar untuk melakukan praktik yang baik dalam perawatan organ genitalia eksternal dibandingkan responden yang menyatakan tidak pernah mendapatkan informasi dari orang tuanya tentang cara perawatan organ genitalia eksternal.

\section{SIMPULAN}

Berdasarkan hasil penelitian yang telah dilakukan, maka dapat disimpulkan bahwa pertama, dari hasil analisis data menunjukan ada perbedaan sikap remaja putri kelompok perlakuan lebih baik dari pada kelompok kontrol meskipun akses media sosial keduanya tinggi. Kedua, ada perbedaan sikap remaja putri kelompok perlakuan yang akses media tinggi lebih baik dari pada kelompok kontrol yang akses media rendah. Ketiga, ada perbedaan sikap remaja putri kelompok perlakuan lebih baik dari pada kelompok kontrol meskipun akses media sosial keduanya rendah. Keempat, ada perbedaan sikap remaja putri di SMAN Kerjo kelompok perlakuan yang akses media rendah dengan kelompok kontrol yang akses media sosialnya tingggi

\section{DAFTAR PUSTAKA}

Effendi, M. 2010. Peranan Internet sebagai Media Komunikasi. Jurnal Dakwah dan Komuniaksi, 4(1).

Indrawati, K. 2013. "Upaya Meningkatkan Pengetahuan tentang Kebersihan Organ Reproduksi Siswi kelas VIII SMPN 10 Surabaya melalui Metode Tutor Sebaya".Jurnal Dinas Pendidikan Kota Surabaya, 5.

Julia, A. R., Yuliatun, L., \& Nastiti, E. M. 2013. Pengaruh Penyuluhan Kesehatan tentang Kebersihan Genitalia terhadap Upaya Pencegahan Keputihan pada Remaja Putridi SMP N 1 Dau Malang. Kurnia, S. S. 2005. Jurnalisme Kontemporer. Jakarta: Yayasan Obor Indonesia.

Notoatmodjo. 2007. Promosi Kesehatan dan Ilmu Perilaku. Jakarta: Rineka Cipta. 
Puspitaningrum, D., Suryoputro, A., \& Widagdo, L. 2012."Praktik Perawatan Organ Genitalia Eksternal pada Anak Usia 10-11 Tahun yang Mengalami Menarche Dini di Sekolah Dasar Kota Semarang". Jurnal Promosi Kesehatan Indonesia, 7(2), 126-135.

Septalia, R.E. 2010."Penyuluhan Kesehatan Masyarakat". Dari http://www. creasoft.wordpress. com. Diunduh 24 Februari 2012.

Undang-Undang Nomor 36/2009 tentang Kesehatan.
Uripni, C. L., Sujianto, U., \& Indrawati, T. 2003. Komunikasi dalam Kebidanan. Jakarta: EGC.

Walgito, B. 2005. Bimbingan dan Konseling (Studi dan Karir). Yogyakarta: Andi.

Wawan, A., \& Dewi, M. 2011. Teori \& Pengukuran Pengetahuan, Sikap, dan Perilaku Manusia. Yogyakarta: Nuha Medika.

Zarella, D. 2010. The Social Media Marketing Book. Jakarta: PT Serambi Ilmu Semesta. 